\title{
The Strategic Response of Dublin's Traditional Department Stores to Intensifying Competition
}

\author{
Edmund O'Callaghan \\ Technological University Dublin, edmund.ocallaghan@tudublin.ie \\ Mary Wilcox \\ Technological University Dublin, mary.wilcox@tudublin.ie
}

Follow this and additional works at: https://arrow.tudublin.ie/buschrsmart

Part of the Business Administration, Management, and Operations Commons, and the Marketing Commons

\section{Recommended Citation \\ O'Callaghan, E., Wilcox, M.: The Strategic Response of Dublin's Traditional Department Stores to Intensifying Competition. Journal of Retail \& Consumer Services, Vol. 8, PP213-225. 2001.}

This Article is brought to you for free and open access by the School of Retail and Services Management at ARROW@TU Dublin. It has been accepted for inclusion in Articles by an authorized administrator of ARROW@TU Dublin. For more information, please contact arrow.admin@tudublin.ie, aisling.coyne@tudublin.ie, gerard.connolly@tudublin.ie.

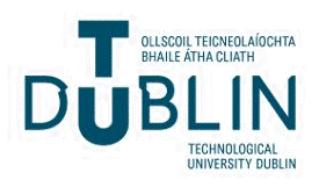




\title{
The Strategic Response of Dublin's Traditional Department Stores to Intensifying Competition
}

\author{
Mary Wilcox, School of Retail and Services Management, \\ Dublin Institute of Technology, Mountjoy Square, Dublin 1, Ireland \\ Tel. 003531 4024218; Fax 003531 4024296; E-mail Mary.Wilcox@dit.ie \\ Edmund O'Callaghan, School of Retail and Services Management, \\ Dublin Institute of Technology, Mountjoy Square, Dublin 1, Ireland \\ Tel. 003531 4024201; Fax 003531 4024296; E-mail EdmundOCallaghan @ dit.ie
}

\begin{abstract}
In Dublin city competition within the retail sector is intensifying and city-centre department stores, in common with other traders, face many challenges. Indigenous retailers must contend not only with each other, but also with an on-going invasion of international retailers who have been attracted by Ireland's booming economy. UK multiples have made major in-roads into Dublin's retail scene and the city centre's latest shopping mall, The Jervis Centre, is so dominated by UK retailers that it has been christened 'Little Britain'
\end{abstract}

In the past fifty years, many of Dublin's once dominant department stores have succumbed to the vagaries of retailing. Now, only three traditional Irish department stores continue to trade. These stores, sometimes referred to as dinosaurs, have managed to survive as the wheel of retailing continues its relentless revolutions. In every direction, new or expanded or refurbished shopping centres and shops are in the process of completion in the city centre, in satellite towns and outer suburbs. By the close of 1997 nearly two million sq. ft. of shopping space will have been built in the capital - the biggest investment in retailing for over ten years.

Dublin's unique 18th century streetscape now provides a backdrop for what has become a recognised cosmopolitan shopping city. The concentrated arrival of British multiples has brought tangible benefits to consumers via greater choice. However, the internationalisation of Dublin's retail scene has led to fears that indigenous Irish companies will be washed away by major UK multiples with greater financial power. While rumours of the demise of Dublin's remaining stand-alone Department stores are constant and obviously exaggerated, undoubtedly these stores have faced difficult times.

This paper considers the strategic response of Dublin's traditional department stores to intensifying competition and provides an insight into the strategic thinking of Irish department store managers.

Key Words: Dublin, department stores, retail sector, retail strategy, shopping centres, city-centre, competition, specialist stores, multiples, fashion, internationalisation, 


\section{Introduction}

In 1993, the value of the non-food retail market in the Republic of Ireland was US\$4.4 billion, up by 33 percent in 5 years. ${ }^{1}$ In Dublin city, the fight for a viable slice of this turbulent retail sector is intense and city-centre department stores, in common with other traders, have been buffeted by the chill winds of competition. As the Celtic economy booms, indigenous retailers must contend not only with each other, but also with an ongoing invasion of international retailers. These retailers, running out of expansion options at home, are looking for an acceptable entry location into the Irish market. The exponential growth in available retail selling space has facilitated their entry and increased competitive pressures.

There is a consensus that industry changes have disadvantaged department stores and the prognosis for their future health is ambiguous, and sometimes negative. Over the years many of Dublin's department stores have succumbed to the radical changes taking place in retailing. Among the survivors are three stand-alone department stores which have traded in the heart of Dublin city since the mid-1800s.

This paper, describes the key changes which have taken place in the city's retail environment over the past ten years and examines the strategic response of Dublin's three stand alone department stores to intensifying competition.

\section{Dublin's Stand Alone Department Stores:}

Dublin city, capital of the Republic of Ireland, is situated on the east coast of the country. In addition to a booming tourist trade, the catchment population for the city-centre shopping area is in excess of one million. This relatively concentrated area has two distinct retailing districts, Henry Street and Grafton Street, separated by the river Liffey and about seven minutes walking time apart. Numerous secondary streets feed off these pedestrianised high streets, particularly south of the Liffey in the Grafton Street area.

Grafton Street, with Trinity College at its base and St. Stephen's Green at its apex, has a distinctly up-market ambience. It has always been Dublin's most prestigious high street and international retailers vie for space there. Both Brown Thomas, and Arnotts/River Island store are located in Grafton Street, as is a new Marks and Spencers store; St. Stephen's Green and Powerscourt Townhouse shopping centres adjoin the Grafton Street area.

Henry Street, adjacent to public transport terminals, has traditionally been one of the strongest shopping areas in Dublin. The success of the ILAC centre, possibly Dublin's best known shopping mall, and the concentration of the city's largest retailers - Arnotts, Dunnes Stores, Penneys, Roches, and Marks and Spencers in one street, contributes to its popularity. The new Jervis Centre shopping mall in Mary Street has boosted the drawing 
power of the area which is now commonly referred to as 'Henry Street Mary Street'. Results from independent market research commissioned by Arnotts department store show that the Henry Street area attracts 21.7 million shoppers annually, compared with 7.1 million for the Grafton Street area. The shopper profile has become more affluent and the area now attracts almost twice as many $\mathrm{ABC} 1$ shoppers annually than the Grafton Street area, 9.5 million shoppers versus 5 million. ${ }^{2}$

O'Connell Street, Dublin's main thoroughfare, is disappointing from a shopping point of view - financial institutions, fast-food chains, amusement arcades, newsagents, jewellers and hotels form the main occupancy. Three outlets provide the only serious retail offer: a flagship Penneys chain store now occupies the premises vacated by $B H S^{\prime}$ s initial failed venture, Easons book store adjoins Penneys, and Clerys department store, a landmark meeting place for generations of Irish people (under the clock at Clerys), is on the opposite side of O'Connell Street's spacious and visually impressive boulevard. The City Fathers now have plans in train to revitalise O'Connell Street as a shopping area, which should benefit the existing traders.

Arnotts, Brown Thomas and Clerys, Dublin's three traditional department stores, located respectively in Henry Street, Grafton Street and O'Connell Street, (see accompanying map) have been part of the fabric of Dublin retailing since the start of the department store phenomenon in the mid-1800s. Each occupies a prime retail site which is its biggest asset. Over the past thirty years many of Dublin's department stores failed to survive; household names such as Pims, Todd Burns, Kelletts, and McBirneys succumbed to competitor pressure and the radical changes taking place in retailing. The latest casualty, Switzers department store, began to sink into oblivion in 1991 when it was bought from the House of Fraser by Brown Thomas.

The commercial ups and downs of each of the department stores are documented in anniversary books which celebrate their survival into the late 20th century. ${ }^{3}$ They make interesting and colourful reading. The parallel between their fortunes and changes in the social and economic fabric of the city emphasises the impact of the external environment on individual firms; their histories mirror the economic and social experience of the people of Dublin. This is well expressed in the book published to celebrate the 50th anniversary of Denis Guiney's purchase of Clerys:

From Butt to Parnell, from the Fenians to the Easter Rising, from the foundations of the Land League to the Eucharistic Congress, from the great lock out of 1913 to the new economic policies of Sean Lemass, Clerys had played a significant role in the changing life of Ireland's capital, witnessing the triumphs and disasters of five generations. ${ }^{4}$

The fact that these three department stores have survived the vagaries of retailing is proof of their stamina. 


\section{Map of Dublin City Centre Shopping Area}

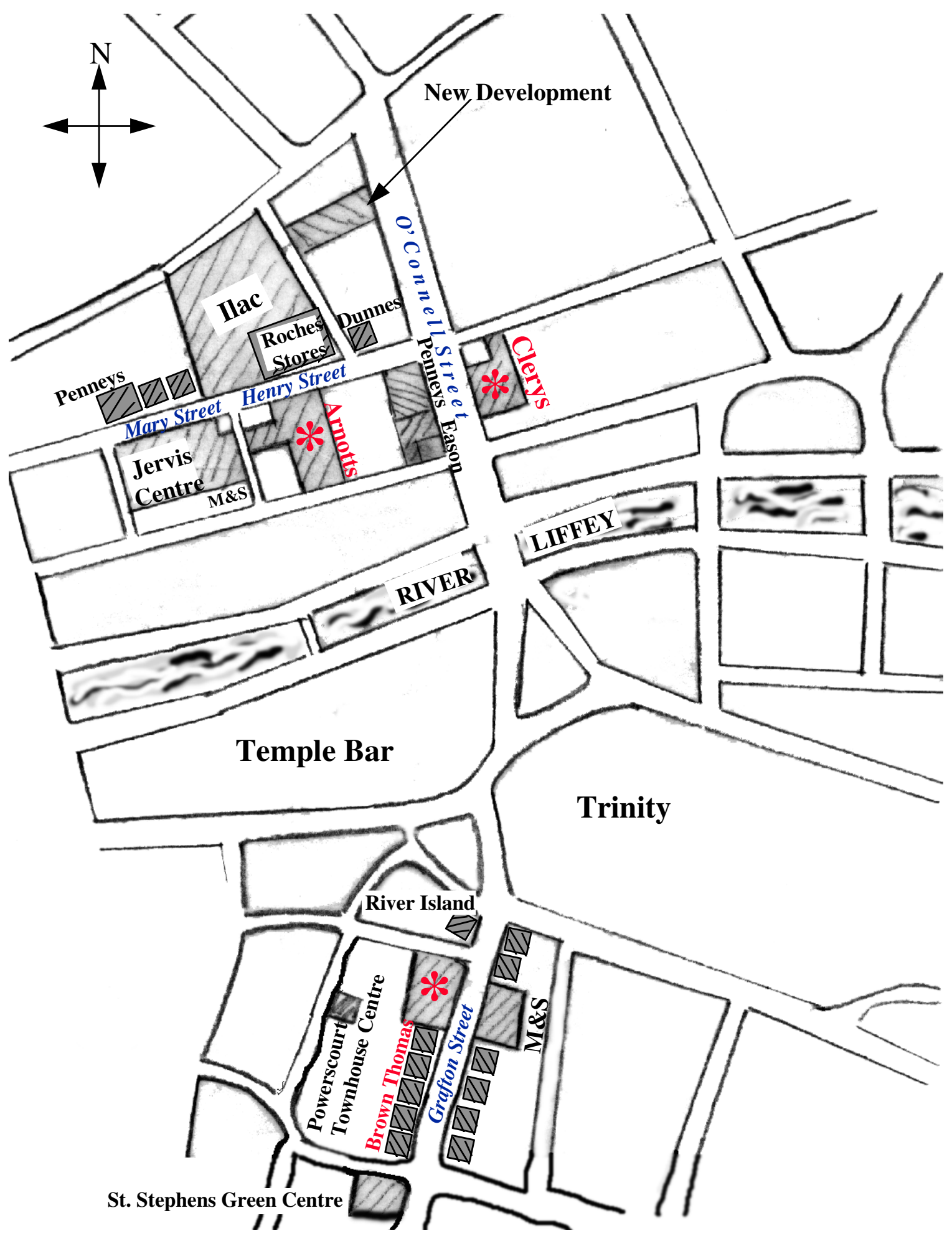


The 1990s has brought a welcome renaissance to Dublin and created a modern cosmopolitan shopping city. This environment is now intensely competitive and, in Darwinian terms, perhaps only the fittest will survive into the new millennium. The following review illustrates the opportunities and threats which department store managers face as the retail environment becomes increasingly complex and turbulent.

\section{The evolution of Dublin into a cosmopolitan shopping city}

In 1997, Dublin was awarded the title of "Europe's Most Improved City for Business" by Fortune, a leading international business magazine. Fortune commented that 'improvements to Dublin's city centre has led to a vibrancy that some people say hasn't been seen since Dublin's golden age 200 years ago'. 5

Several interlinking factors contributed to Dublin's current high standing:

- The pro-active approach of The Dublin City-Centre Business Association (DCCBA) in improving the shopping environment in the city.

- A policy of inner-city renewal which offered tax incentives and rent rebates and encouraged property developers to rejuvenate designated sections of the inner city.

- Ireland's Celtic tiger economy which boomed in the early 90s following stringent, but successful fiscal policies.

- Favourable economic and industry circumstances encouraged indigenous retailers to up-grade their offer and attracted large numbers of international retailers to locate in Dublin.

\section{City-centre improvements}

Although the US opened its first regional shopping centre in Seattle in $1950^{6}$, it was the late 60s before such developments blew winds of change through Dublin's shopping scene. In 1966 the first planned shopping centre development opened in Stillorgan, by the end of the 1960s nine shopping centres had opened in suburbia. The increased competition from an ever growing number of out-of-town shopping centres was a major threat to city centre retailers. In the early $70 \mathrm{~s}$, as regional shopping centres began to develop throughout the rest of the country life became even tougher for Dublin retailers.

The first city-based shopping centre was built in 1979 and since then many centres have been opened. The novelty of the shopping centres changed the flow-path of shoppers, e.g. research experts say that Henry Street, north of the Liffey, showed a decline in pedestrian flows of $45 \%$ in 1988, coinciding with the opening of the St. Stephen's Green Centre. In 1990, Grafton Street showed a significant drop in December pedestrian flows, when The Square opened in Tallaght and it took until 1993 for normal footfall levels to

recovery. ${ }^{7}$ As traders lost out to suburban and regional shopping centres, city-centre 
businesses also had to contend with a rising crime rate in Dublin city, traffic congestion, and poor parking facilities.

Since the early 1980 s the $D C C B A$ has been fighting to provide an ambience which would attract shoppers back into the city. Retailers were encouraged to refurbish and up-date shop fronts and to standardise shopping hours. Over the years, improved security arrangements, pedestrianisation, additional car parks, attractive street furniture, seating, shrubs, lighting, litter bins and art work have been put in place to create a pleasant environment that has dramatically improved the city's shopping environment.

\section{Inner-city renewal}

The planned urban regeneration programme, which was EU and government funded, succeeded in revitalising the city, e.g. the rejuvenated Temple Bar area project in the inner city is credited with creating 1,930 long-term jobs in the cultural and services industries. From being a semi-derelict part of the city, Temple Bar now succours 160 new business, and pedestrian number through the area have trebled since $1991 .^{8}$

Between 1971 and 1991, the population of Dublin's inner city had fallen from 131,503 to 76,558 , a drop of almost 50\%. Since 1991, there has been a reversal of that trend and over 14,000 people have moved in to live in the centre city; this number is expected to rise to over 25,000 by the end of the decade. The great majority of the new influx of residents are young people, mostly single, giving a new vibrancy to Dublin. ${ }^{9}$

In the three decades to 1996, the growth in retail selling space had been steady, but unspectacular; 3.5 million square feet of shopping space had been developed in the city and suburbs. ${ }^{10}$ Since 1996, over 1.5 million square feet of purpose-built shopping space has been developed in the capital; during 1996/97, an estimated $£ 400 \mathrm{~m}$ was invested in Dublin's city-centre and suburban environs. Government tax and rent incentives encouraged major development in the Henry Street Mary Street area, which included the new Jervis Centre and a massive extension to Arnotts department store. ${ }^{11}$

\section{The Celtic Tiger Economy}

As the Irish economy continues to grow more strongly than that of any other OECD country, a strong growth in real disposable incomes, further gains in employment, rising asset prices and expectations of falling interest have all contributed to fuelling consumer spending. In 1997, GNP grew by an estimated 8.5 to $9 \%{ }^{12}$, this compares favourably with a $2.5 \%$ overall growth in Ireland's main trading partners. Employment grew by an estimated $4 \%$ and a further increase of $3.5 \%$ is expected in $1998 .{ }^{13}$ Positive economic circumstances have created more than 77,000 new jobs in the city between 1990 and 1997. Demand for housing is unprecedented; the consumer 'feel-good' factor is tangible and is reflected in the number of new cars on the road, an increase of 25,000 (105.5\%) between 1993 and $1997 .^{14}$ 
From a retailing perspective, the down side to these positive developments is that mortgage and car loan repayments reduce discretionary spending capacity, although both the Retail Sales and Retail Volume Index remain healthy. The volume index increase of

$7.9 \%$ in 1997 is higher than in any other year in recent history, ${ }^{15}$ while the consumer price index increased by only $1.5 \%$ on an annual average basis. ${ }^{16}$

\section{The internationalisation of the retail environment}

The Irish retail trade has been revolutionised over the last eight years by an explosion of concession shops, specialist chains, UK and other multiples opening in the capital. Indigenous retailers have risen to the challenge posed by new traders and new formats by up-grading and extending premises. Arnotts, Brown Thomas, Clerys, and a myriad of other smaller stores, have invested heavily in refurbishment, and sometimes in massive expansions. Established international retailers, e.g. Penneys and Marks and Spencers are also investing for the future.

In the late 60 s and through the 70 s and 80 s, some UK retailers opened stores in Dublin, with mixed results - BHS, MFI and Tesco were among the failures, but some early entrants, e.g. Marks and Spencers and Laura Ashley traded successfully. Although the early 90s had seen a consistent trickle of UK multiples into the Dublin scene, the availability of prime retail space in the city centre in 1996 fuelled what is commonly referred to as the 'invasion' of British Multiples into the Dublin Market. However, while the perennial tug-of-trade between inner city and the suburbs was broadly counterbalanced by the near simultaneous opening of both the Jervis Centre in the city and Blanchardstown Shopping Centre in the suburbs, the tenancy of these new centres epitomises the UK retailer phenomenon.

Covering 330,000 square feet and costing $£ 50$ million, The Jervis centre provided a springboard into Dublin for big-name UK retailers, e.g. Boots, Dixons and Debenhams. $B H S$ used the centre for its second coming into the Irish market; Marks \& Spencer's Mary Street store links into the Jervis centre. Jervis is so dominated by UK retailers that Dublin wags have christened it 'Little Britain'. In Blanchardstown, almost a quarter of the total space of the $£ 100$ million, 650,000 square foot shopping centre was taken by retailers from Britain and Northern Ireland. ${ }^{17} 1996$ was also the year of the LSU (Large Space User). In the new retail warehousing park opened at Blanchardstown Town Centre, electrical retailer Currys is trading out of a 30,000 square foot superstore, while its sister company, PC World, has taken 20,000 square feet Marks and Spencers, Boots and Tesco will be anchor tenants for Dublin's new Liffey Valley shopping centre opening in Autumn 1998. Some of the newer arrivals have accelerated their expansion through acquisition, e.g. Boots has taken over a well-known chain of chemist shops, Hayes Conyngham \& Robinson and thus achieved entry into ten prime locations in Dublin city and suburbs.

The internationalisation of Dublin's retail scene has led to fears that indigenous Irish companies will be washed away by major UK multiples with greater financial power and 
that the traditional diversity of Dublin's shopping scene will be lost. The following description, titled 'A Stroll Down Grafton Street', catches the flavour of what is happening in Dublin city:

A walk down Grafton Street immediately reveals that the personalised stores of days gone by - including the Monument Creameries, the Eblana book shop and McConnells - have all been replaced by UK chain stores like Jigsaw, Miss Selfridge, Monsoon and Warehouse. But the dubious delights of so-called Euroshopping in the form of McDonalds, Dunkin' Donuts, Burger King, HMV, Tie Rack and Sock Shop are all much in evidence. If you add to these the bulk of the remainder of the stores on Grafton Street - Laura Ashley, Next, Principles, River Island and The Body Shop, not to mention Marks \& Spencers - you end up with a street which is predominately British and remarkably similar to the average UK high street. ${ }^{18}$

Property experts anticipate that the demand for retail space will not be confined to UK retailers; $C \& A$, a big-name Dutch retailer, is using the new Liffey Valley centre as its entry point to the Irish market. As the number of US retailers expand in Britain, they are expected to target Ireland, particularly Dublin ${ }^{19}$. US retailer, Gymboree, has located in Grafton Street and TK Maxx has acquired premises at St. Stephen's Green shopping centre.

In response to increased demand for units, Zone A rents in Grafton Street are expected to break the $£ 200$ per square foot barrier. While high street rents are now out of reach of many retailers, this has brought about a regeneration of many side shopping streets, e.g. South Anne Street and Wicklow Street which adjoin Grafton Street, have both been revitalised. To some extent, all retailers have benefited by improved footfall throughout the city. ${ }^{20}$

Dublin's unique 18th century streetscape now provides a backdrop for what has become a recognised cosmopolitan shopping city. The concentrated arrival of British multiples has contributed to the city's buzz and has brought tangible benefits to consumers via greater choice; the improved choice has stopped the drift of Dublin consumers to Belfast for Christmas shopping and people from outside Dublin who stopped shopping there during the 80 s and early 90 s have been tempted back.

\section{Department Stores and retail strategy}

While the gambit of strategy determinants are multiple and complex, many of the issues of strategic development are concerned with changing strategic capability to fit a changing environment better. ${ }^{21}$ Devising a successful strategy is a challenging process; a successful strategy gains and maintains competitive advantage, a less than successful 
strategy leads to strategic drift. Four factors, efficiency, quality, innovation and customer responsiveness, are the generic building blocks of competitive advantage. ${ }^{22}$ Ansoff's Product/Mission matrix and Porter's Generic Competitive Strategies provide a conceptual framework within which to consider strategy decisions. ${ }^{23}$ Figure 1 shows the mix of inter-related development strategies which managers can exploit to gain and maintain competitive advantage.

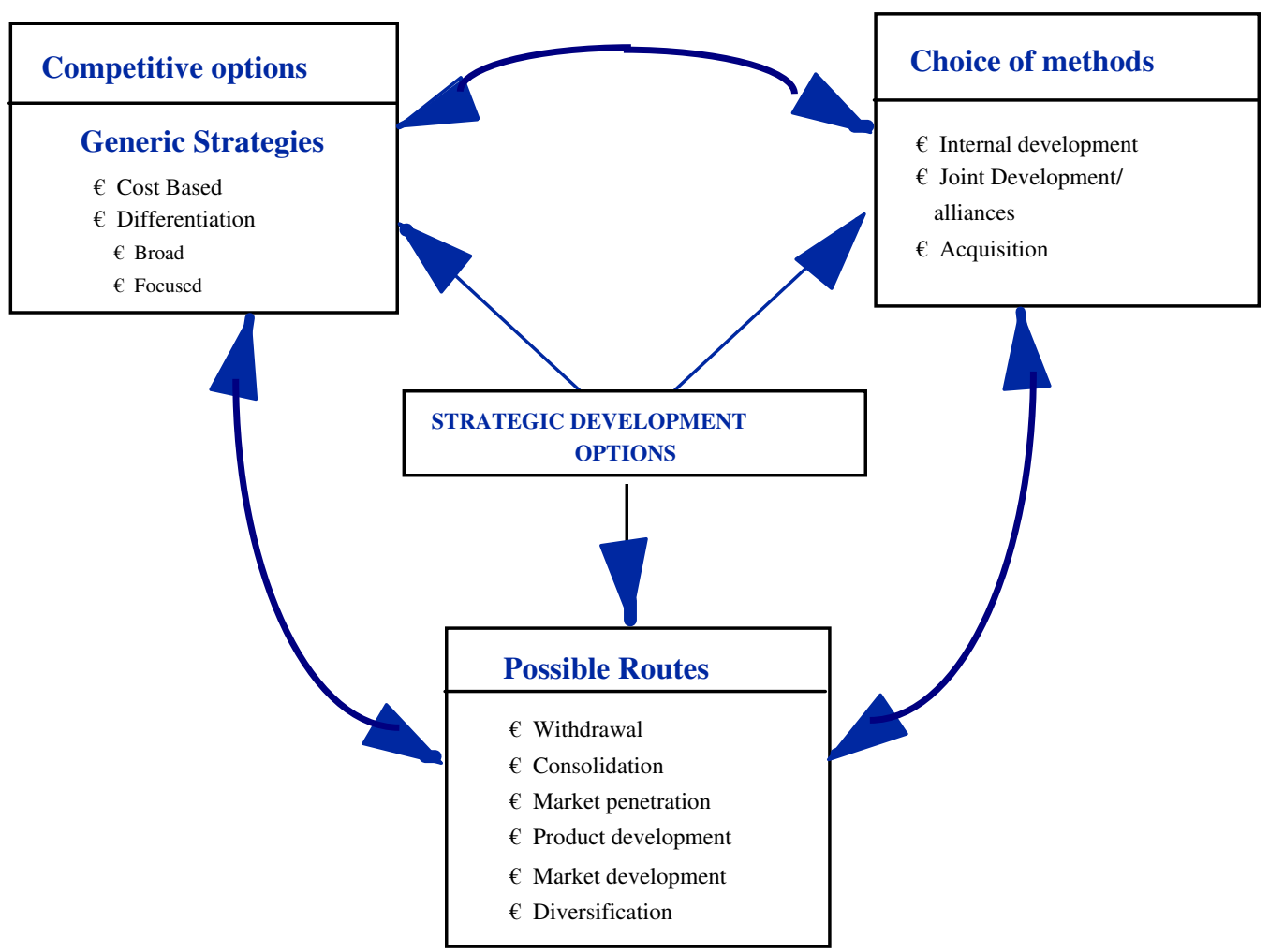

Figure 1: Inter-Related Development Strategies

Daivd Walters in his book Retailing Management: Analysis, Planning and Control proposes a strategic and operational decision model which reflects how strategy develops within a retailing enterprise, and which includes the elements of time and return. ${ }^{24}$ Figure 2 illustrates. 


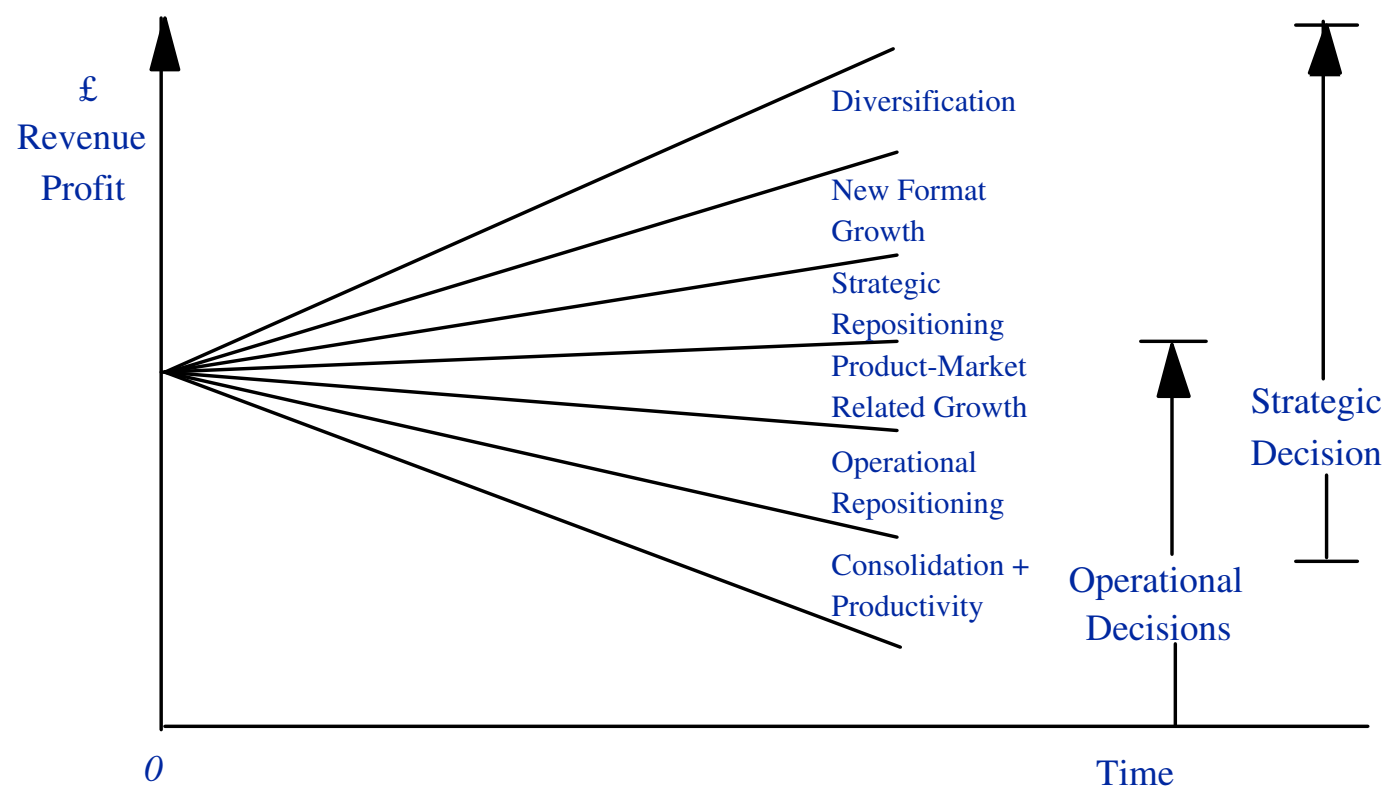

Figure 2: Strategic and Operational decisions

Source: David Walters (1994) Retailing Management: Analysis, Planning and Control. Reproduced with permission from The MACMILLAN PRESS LTD., Basingstoke, UK

Consolidation and productivity is concerned with improving performance from the existing base, operational repositioning may require small, incremental adjustments to service and merchandise attributes to maintain customer loyalty, product/market growth refers to growing the existing business, strategic repositioning refers to revising a company's image to attract new market segments, new format growth involves developing new offers which are based upon an existing format, e.g. a successful specialisation, within a larger format, may become a multiple operation in its own right.

Strategic decisions can be placed on a continuum which relates strategic choice to risk and reward. Low risk strategies such as consolidation and market penetration are likely to be least rewarding, but high risk strategies which involve substantial investment in growth should attract a high return. Figure 3 shows the theoretical relationship between operational and strategic decisions and risk and return. 

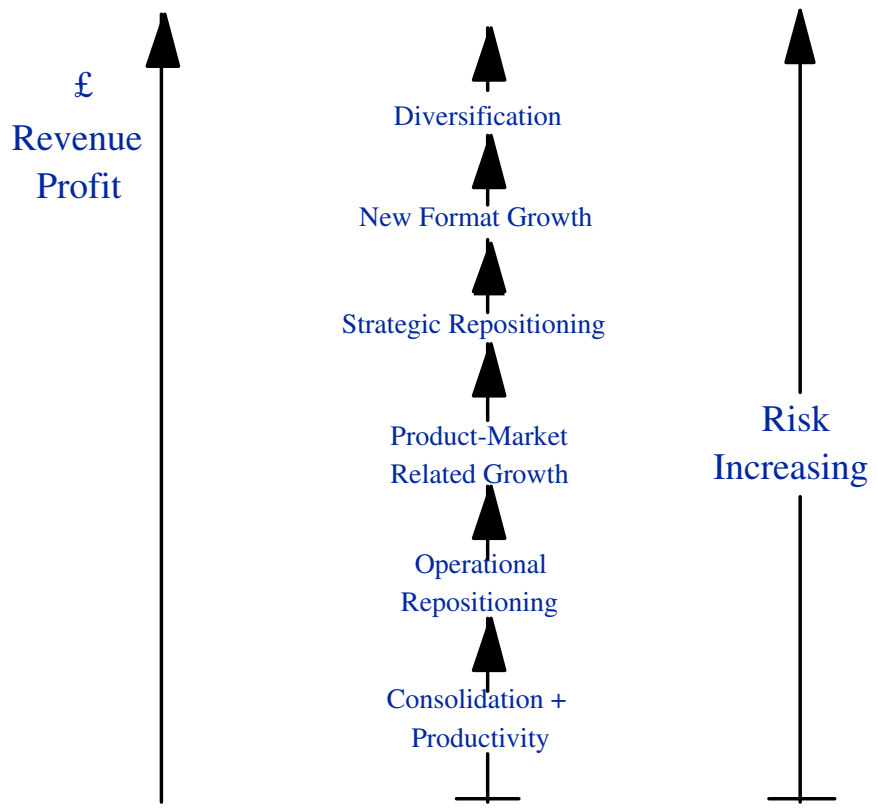

Figure 3: Strategic decisions, Risk and Returns.

The literature suggests that traditionally, retailers tended to be stronger on tactics than on strategy; ${ }^{25}$ more concerned with 'reacting quickly and positively in order to meet the day-to-day problems of running their businesses in a fast-moving and highly competitive environment'. ${ }^{26}$ Omura pointed out that when discussions on the strategic planning concept took place in academic and management circles, the focus was on manufacturing firms, with less attention being given to the application of these concepts to retailing firms. ${ }^{27}$ Nowadays, few would argue with the contention that retail strategy must respond to changes in the structure of the industry and the nature and rate of social and economic change. While reactive strategies may suffice when the external environment is changing slowly, 'in a turbulent environment, reactionary responses may be fatal. ${ }^{28}$

Davies \& Brooks (1989) argue that for retailers: "By comparison with other business sectors, from a strategic perspective, suppliers, customers, potential entrants and substitutes are less important than the competition that exists within any one particular sector". ${ }^{29}$ Certainly, companies play an important part in shaping the markets in which they compete, ${ }^{30}$ thus the generic strategies (cost leadership/differentiation/focus) adopted by rival firms is inextricably linked to the evolution of markets. ${ }^{31}$ The way one company changes or fine-tunes its strategy over time affects the way the other companies in the industry pursue theirs. The intensity of competitive rivalry makes it difficult to maintain an exclusive 'position' within a market and by the mature stage of the industry cycle, competitors inevitably appreciate how interrelated their strategies are. ${ }^{32}$

As detailed earlier, the competitive environment in Dublin is intense and is likely to become more so as international retailers now perceive fewer barriers to entry to the 
Dublin market. ${ }^{33}$ The end result of the industry structure changes is that an increasing number of competitors are jockeying for position. Berry points out that 'overstoring' puts pressure on companies as "the level of retailing effectiveness required for survival continues to rise." ${ }^{34}$

All companies are concerned with establishing a basis on which to build sustainable competitive advantage, but it is widely accepted that, on a global basis, industry changes have had negative consequences for department stores; it is even suggested that traditional department stores, sometimes termed the dinosaurs of retailing, may be in the declining stages of the retail life cycle. ${ }^{35}$

From the 60s on, several social factors simultaneously disadvantaged department stores. Rising car ownership gave consumers mobility, but department stores, built in an earlier era and mainly located in high streets, couldn't capitalise on this because they lacked parking facilities. In theory, the social mobility which swelled the middle classes and the increased prosperity which flowed from dual income families should have benefited department stores. However, more women joining the work force left less time for leisure shopping and rising incomes and changing lifestyles changed the emphasis from value to rapidly-changing fashion. Ominously, the most potent threat to department stores came from the proliferation of multiple and specialist chain stores which crowded into high streets and new urban shopping centres.

Although traditional department stores would never have aspired to cost leadership, multiples and specialist chain shops, because of their critical mass and product concentration, have considerable clout with suppliers; they can source and market goods more cheaply than can a single, diffusely stocked, department store. In today's competitive environment, other operational handicaps - high staff costs associated with quality service, high maintenance costs associated with large buildings and high stock costs associated with a wide range of product offerings, some of which are bound to be slow-moving, put department stores at a cost disadvantage.

Differentiation, once the hallmark of department stores, is now problematic. Davies and Brooks put forward the view that focus is synonymous with market segmentation and that segmentation and differentiation are associated retailing strategies, commonly referred to as 'positioning'. ${ }^{36}$ Johnson (1987) describes the many benefits that can flow from a successful positioning strategy: higher barriers to entry for competitors, high customer loyalty, more price-flexibility, slimmer stock, reduced supplier power. ${ }^{37}$ However, successful positioning strategies may be rapidly imitated ${ }^{38}$ and the bases for differentiation may change over time. Establishing a clear target market is intrinsic to successful positioning, but problems arise when everyone 'shoots at the same target'. ${ }^{39}$ 
Specialist and chain stores are well-positioned to pursue a focus differentiation strategy. Specialist stores often offer customers a deeper and wider choice of goods than the Department store can feasibly supply. Fashion chains such as Next and Oasis target very specific market segments with highly focused product offers. Market development strategies pursued by Multiples are based on what has been called a generic strategy of multifocus differentiation, ${ }^{40}$ supported by a low cost base accrued through economies of scale. Some of these multiples have been likened to 'diversified merchandise conglomerates', ${ }^{41}$ e.g. among its repertoire, Burtons has Top Shop and Top Man for the younger market and Principles for fashion buyers. In contrast, because of the diffuse nature of its offerings, department stores can run into problems because 'the store itself, the fixtures and fittings, the decor and store ambience, and the staff may not be differentiated according to the different market segment needs'. ${ }^{42}$

Increasingly, department stores have become 'stuck in the middle'43 as they be struggle to adjust to the industry changes. Traditional advantages like the 'everything under one roof' concept offered by department stores lost its special meaning when in-town and outof-town shopping centres began to provide alternative, somewhat comparable, and more convenient, shopping venues. The ubiquitous credit card has undermined the advantages of the original department store card which imputed a measure of prestige to the holder and was designed to encourage loyalty. Irish consumers are now offered a surfeit of loyalty cards from chain stores and supermarket outlets which reward a purchasing consumer with accumulated points which periodically translate into cash vouchers. Dunnes Stores 'Value Card' and Tesco's 'Club Card' are examples of this system in action. It is argued that customer loyalty is fundamental to the survival and prosperity of department stores; ${ }^{44}$ a counter-argument by Davies and Brooks ${ }^{45}$ puts forward the view that because switching costs are so low, a retailer's most fickle asset is customer loyalty; that segmentation is problematical and that 'customers can and do move from one segment to another, altering their purchasing behaviour to suit a purchasing occasion, a short-term change in financial circumstances, or a change in mood'.

A strategy of broad differentiation, unique in terms of dimensions widely valued by buyers but different from competitors, ${ }^{46}$ may be a viable option for department stores. Bradley and Taylor argue that the requirements for competitive success in the retail sector are changing; that while sites, technology and merchandise are still important, the emphasis in terms of critical success factors has shifted to human resources ${ }^{47}$ which is a new development for the retail sector. There is a new 'focus on service and on the interface between customer and staff'. ${ }^{48}$ This is an area where department stores should have a particular strength; they come from a tradition of service which, with some notable exceptions, is largely alien to the self-service culture of the chain store multiples. However, sensitivity to customer service has risen across all sections of retailing and services and recent UK research has shown that sadly, the quality of department store service now fall well short of the standards of some other retailers. ${ }^{49}$

Department stores world-wide would appear to have been guilty of strategic drift. The challenges which department stores must meet in a hostile competitive environment 
highlight the difficulty of carving out a distinctive competitive advantage and the prognosis for department stores is ambiguous. While authors detail their decline in the US, in Europe and in Singapore, these same commentators, and others, also acknowledge that department stores are implementing survival/revival strategies which are working, e.g. closing weaker stores, dropping uncompetitive specialist departments like electricals, rationalising product line to concentrate on the high-margin fashion sector, increasing concessions, reducing staff numbers and to a limited extent replacing full-time staff with part-time workers. ${ }^{50}$

More pro-active growth strategies have seen department stores diversifying into alternative retail options such as mail order or specialist shops, developing own brands, investing in major refurbishment - especially of flagship stores, and expanding outwards from traditional high street locations to become anchor tenants in shopping malls.

\section{A summary profile of Dublin's Traditional Department Stores (1988-1998)}

\section{Arnotts}

Arnotts flagship store has traded from its Henry Street site since 1843. The parent company also trades from two smaller department stores, Boyers in North Earl Street and Arnotts/River Island Franchise in Grafton Street and from a shoe store in Stillorgan shopping centre.

1988, a litmus year for Arnotts, saw the company take some hard decisions. In the previous year, high in-store costs had forced the company to rationalise departments and look for staff redundancies. Following a succession of poor trading results, both its wholesaling and manufacturing businesses were shed and Ballet International was sold off. The closure of wholesale freed-up $£ 3 \mathrm{~m}$. for reinvestment in retailing and the company decided to up-grade both its range of merchandise and its store. It used the extra space to build on its reputation for instore events, inviting celebrities, media and sporting personalities to meet customers in its Henry Street store. Electronic Point of Sale (EPOS) was installed in 1990.

1991 was an active year. The company opened its shoe store in Stillorgan shopping centre and a $£ 5$ million in-store reconstruction programme was started in the Henry Street store which increased space by 20,000 square feet. When the new interior was completed in 1992, a new balcony fashion gallery allowed the store to improve its concession offer. A River Island franchise got space in the lower ground floor and was so successful that Arnott's Grafton Street store is now shared with the River Island franchise. A Manchester United Memorabilia outlet was an added attraction. Following these improvements Arnotts enjoyed a doubling of profits between 1988 and 1992; margins improved from $4 \%$ to $9.6 \%$.

In 1994/5 the company took advantage of tax shelters. Using company property, most of which fell within the tax designated area, Arnotts started a massive extension $(130,000$ 
square feet) of its Henry Street Store It also made a tax beneficial investment in the Irish made 'Michael Collins' film. The new store, which opens onto three streets, now has 320,00 sq.ft. of selling space and is the largest department store in Ireland and the fifth largest in the UK and Ireland.

Arnotts used the additional space to increase the range and depth of proven departments like men's and women's fashions, furniture and children's clothes; 25,000 square feet is dedicated to its children's offering of fashion, footwear and toys - all major brands are stocked and the company has one of the best selections under one roof for children 'people will feel that they will have to look here first, even if they don't buy.' Product range has been extended via a concession to Courts Electrical and product adjustments have seen Arnotts buyers alter their furniture strategy to include a range which caters for the new city dwellers living in smaller apartments.

To support a 'one stop shop' concept, its four restaurants offer breakfast, lunch and afternoon tea and its product range is comprehensive. An in-store ATM and Bureau de Change facilitates everyday shoppers and tourists. The company is currently investing $£ 6$ million in redeveloping the ground floor of the Henry Street store; it has opened a section of its 'Impulse Department' which includes the concessions Kookai and Esprit to cater for the 18-35 year old female. In 1997 a multi-storey car park was added and from September 1998 the company will extend its opening hours and trade on Sundays from 12 noon to 6 p.m. Later this year a 3,500 square feet exhibition hall will be opened, as will an 18,000 square feet discount centre. This centre will offer bought in 'specials' and clearance merchandise.

Arnotts sees its image as 'middle to better' and defines its mission statement as aspiring to be 'The Department Store', a theme which is also carried in its advertising. 'One Stop Shop' is the positioning strategy - to be the authoritative department store offering variety, choice, brands and value. The store is brand led and a lot of its advertising is in terms of 'top name specials' which highlights brands and prices. The mix of concession shops is weighted towards the growing, more affluent $\mathrm{ABC} 1$ shoppers. While acknowledging that the Jervis shopping centre has improved the city centre shopping offer, as part of its competitor tactics management makes sure that the company is not undersold by any trader in the Jervis shopping centre.

The ability to make retailing entertainment, to 'keep changing, to keep adding products, to present an Aladdin's cave with display, presentation and merchandising' is thought to be critical. The company sees its reputation for service and product knowledge as key success factors and staff training to support this is an on-doing process. To date, the company has invested $£ 50$ million developing the store and has no plans to move outside the Dublin area. 


\section{Brown Thomas}

Brown Thomas, established in 1848 by Hugh Brown and James Thomas, lays claim to be Dublin's most prestigious, up-market department store. During its 150 years, the store has changed hands many times. From 1919-33 it was owned by the legendary American, Harry Gordon Selfridge, a visionary exponent of department stores. In 1970, when there was talk of the store closing down, it was bought by Galen Weston, a wealthy Canadian whose family property included the famous department store, Fortnum and Mason.

(Weston is married to Hiliary Frayne, a top Irish model, who had been associated with Brown Thomas fashion shows. Mrs. Weston is often cited as the inspiration behind the Weston purchase of Brown Thomas.) ${ }^{51}$ A brief flirtation with the Stock Market ended in 1983 when Brown Thomas returned to family ownership and became the personal holding of Gale and Hilary Weston.

In 1988, The Brown Thomas Group consisted of the Brown Thomas Speciality Store, a chain of 'A-Wear' stores which targeted a younger market (fashion conscious but budget restricted), and the Bailey Pub in Dublin's Duke Street.

The company generated shock-waves throughout the Irish retail sector when, in 1991, it bought the ailing Switzer Group from the House of Fraser. (Switzers Department Store, situated across the street from Brown Thomas, had graced Grafton Street since 1838 and had been bought by Waterford Glass and a subsidiary of the House of Fraser in 1971). In addition to the flagship store, Brown Thomas also acquired three well-established department stores, Cashs of Cork, Moons of Galway and Todds of Limerick. The unexpected acquisition laid the way for an even bigger sensation two years later when it was announced that the two shops on Grafton Street were to merge.

Brown Thomas spent $£ 23$ million creating a new store on the Switzers premises, but the Switzer name, which signified an upper-middle bracket department store, was dropped. The redesigned store had floor space of 158,000 square feet. In 1995 the new store opened to acclaim and in its first year won an award as 'The Best Department Store in Ireland and the UK'.

In 1987/88 Brown Thomas was planning its strategy for the 90s. It started by implementing a process of staff rationalisation concurrent with negotiations with the House of Fraser for the purchase of the Switzers Group. Poor trading conditions and the extra costs associated with these redundancy payments led to accumulated losses of over $£ 2$ million in 1990 , but by 1991 these losses had fallen to $£ 907,000$ as the benefits of rationalisation came through.

In 1993 Brown Thomas discontinued the Switzer and Brown Thomas store cards and replaced them with a Brown Thomas master credit card which offers customers a $10 \%$ discount across all Group stores. 
With the merger, Brown Thomas management set out to 'create a totally new business, to combine the best of the two businesses under one.' While Brown Thomas' business lay mainly in the high end of men's and women's fashions and accessories, Switzers strengths, in addition to its fashion departments, lay in electrical, kitchenware, soft furnishings and glassware. Maintaining the same price structure, these departments were incorporated into the new store. The merger changed Brown Thomas from a speciality store to a department store. Because retail selling space was tighter in the new store, some concessions had to go and there was a further degree of staff rationalisation. Innovations included additional services e.g. two new restaurants, an interior design consultant, and a personal shopping service targeted at the corporate sector. EPOS, which was not in either business prior to the merger, is installed in the new store. Brown Thomas was the first traditional department store to open for business on Sundays and Bank Holiday Mondays.

In 1997 a new 350 car park facility was added; in 1998 a Brown Thomas (BT2) store devoted to designer sportswear was opened on the old Marks and Spencers site in Grafton Street. The company is in the process of developing and refurbishing its other department stores. The Cork store, originally Cashs of Cork, is now Brown Thomas Cork. As each department store project is completed, the store will be renamed.

Brown Thomas describes its target market as "middle to upper - Ireland doesn't have enough 'top-top customers' to make this segment on its own viable". Market research undertaken in the planning stage showed that, despite the move, Brown Thomas customers would be loyal, but Switzers customers were wary of the Brown Thomas name, which connoted higher prices. The traditional Brown Thomas customer was upper middle class, in the 40-55 age bracket. While acknowledging that some Switzers customers have been lost, management says that the new store has found a new breed of customer - younger (aged 20-30) and affluent - who previously didn't shop in either Brown Thomas (because of its older image) or Switzers (because its product range didn't meet their needs). These younger, affluent, well travelled people find the new store more contemporary and on a par with stores in the US and Europe.

In terms of differentiation, management is satisfied that the name of Brown Thomas is synonymous with service but the amalgamation of different environments and different cultures posed challenges. Merchandise is also distinctive - 'the same mix of merchandise doesn't exist in any other Irish department store, or even in any combination of other department stores'. Sixty per cent of products stocked are exclusive to Brown Thomas and the new stock reflects the change in the store's segmentation strategy - new brands, e.g. Mac make-up and new labels - Tommy Hilfiger, Versace, and DKNY add a young image appeal and the revamped men's department is extensive. 
The new Brown Thomas has a mission statement which aspires to be the top department store in Europe in terms of merchandise, people, customer service, environment and profitability. New arrivals, e.g. Debenhams in the Jervis Centre have had no impact on strategy - "we don't constantly look over our shoulder - we have our own vision - we set the standards". The company has no plans for expansion within Ireland, but would consider moving abroad if the right opportunity arose.

\section{Clerys}

Clerys foundations go back to 1853. Situated on Dublin's main civic thoroughfare, O'Connell Street, the store has long been associated with the name of Denis Guiney, legendary in Dublin's retail circles, who rescued Clerys from bankruptcy in 1941. A Guiney's original department store (famous for its sales and discounted merchandise), Clerys the Square, At Home with Clerys, plus the flagship Clerys, remain under the control of the Guiney family. Denis Guiney's widow, Mary, is Chairman of the company and although now in her 90s, she regularly attends Board meetings.

Clerys store has a four floor structure and 115,000 square feet of selling space. Because O'Connell Street is not a browsing street, Clerys could be termed a 'destination' store' people who shop in Clerys do so with a large amount of prior intent. Its size, location and Irishness draws a strong tourist trade and it provides a direct mail service for tourists as well as a bureau de change.

Boosted by the Millennium celebrations, 1988 was a good trading year for Clerys, it was also the year in which Clerys introduced a concessioned Ms. Selfridge to the Dublin market. In 1992 a new Chief Executive was appointed. In that year also, Clerys the Square store was opened in The Square shopping centre in Tallaght and several attractions were added to the main store: four concession run restaurants, a Scholl's shoe department and a new sports department were among the new offerings. Unfortunately, adverse economic circumstances and the difficult trading conditions which prevailed in 1992 saw profits fall by $2.5 \%$ and the following year the company was forced to seek 60 staff redundancies.

In 1994 market research revealed that Clerys appeal was predominantly to the older customer, particularly males aged 50 plus. The company put in train a three year development plan, which involved targeting a new generation of 25 to 40 year old customers, mainly female, developing a corporate identity in terms of customer communications, enhancing the store, training staff, and improving procedures.

Initially the focus was on getting the product right; produce lines were rationalised, merchandise was upgraded and a wide range of fashion concessions, which are reviewed on a six monthly basis, was introduced. Many of these concessions were initially exclusive to Clerys, but this is no longer the case; Clerys, Arnotts, Brown Thomas and Debenhams endure a degree of overlap and some concessions have opened independent outlets. However, buyers are constantly focused on acquiring new brands. The store now 
carries a comprehensive range of branded fashions to suit females of all ages and sizes. A 'Jean store' and targeted concessions strengthened the younger men's fashion offer and Ladybird books and clothing for children was introduced as an additional attraction to the children's department. Weekday trading hours were extended and following a substantial investment in information technology, EPOS was introduced in May of '96. In 1997 the store opened an additional 11,000 square foot furniture showcase in Leopardstown Retail Park in South Dublin.

The implementation of the store and staff development programme, due to commence in 1997, was deferred to 1998. It was decided to take another year out to ensure that the design features and the placing of departments within the store were exactly right. In 1996 the store had 23 traditional Clery departments and 40 concessions; today the emphasis has changed and Clerys has 37 own bought departments and 38 concessions. It has just launched an instore 'Irish only shop' which promotes Irish brands.

Both the refurbishment and staff development programme are now in hand and the first phase of the $£ 7$ - $£ 10$ million refurbishment plan to modernise the interior is underway. Negotiations are complete to introduce several new concessions which will be exclusive to the Irish retail market and attractive to the 25-40 female market. In 1998 Clerys became one of fifteen companies associated with the newly introduced Hibernian Swift Points Master/Loyalty Card.

Clerys is happy to see itself as a middle-market department store which is heavily branded and on the way to being well-positioned. It is gradually shedding its oldfashioned image. It seeks to offer quality branded products, providing value and choice for its customers. Staff who have been with the company for year have a well-engrained culture of customer service and deep product knowledge. Because few concessions are now exclusive to Clerys, differentiation is hard to achieve, but the company sees its 'Dublin' image and the comfort of shopping in Clerys as sources of competitive advantage.

The company formally considered the impact of the Jervis centre opening, but didn't see any reason to change its present strategy, which is reviewed on a yearly basis. Managing change is a gradual process and the company feels that it has come a long way in four years. It currently has no plans to extend or expand.

\section{Discussion}

Dublin's traditional department stores are vigorously implementing a range of strategies to enable them to survive and grow; the changing nature of the Dublin market has acted as a catalyst. As is usual for strategic groups within an industry, their strategies have common elements, but they also have key points of difference. Their approaches range from proactive to reactive and from high risk to low risk; the results of these strategies are also varied. 


\section{Common Approaches:}

\section{A blend of generic strategies}

Dublin's traditional department stores continue to develop a generic strategy of broad differentiation based on adding value for customers through service, quality, brands and reputation which are seen as critical success factors. Within this dominant strategy, the development of specialisms suggests that the stores are moving towards selectively incorporating focus strategies which build on their strengths, e.g. Arnotts gave more space to already successful departments, Brown Thomas opened a designer sportswear store. The development of specialisms is a competitive response to industry changes which attempts to provide a depth and width of range which will appeal to specific market segment needs.

\section{Development Routes}

When the vicissitudes of the economy and market changes undermined profitability, the stores engaged in consolidation/protection strategies aimed at containing losses and improving productivity: staff numbers were reduced, product lines were rationalised and technology was up-graded. Although time periods and time scales differ, for each company its consolidation strategy acted as the foundation stone for future growth. The stores did not confine themselves to one development route; in 1988, Arnotts managed to simultaneously implement a withdrawal, consolidation, and growth strategy as it withdrew from manufacturing and wholesaling, rationalised departments and reduced staff numbers, and invested in store improvements.

An intrinsic component of the department stores' strategy is incremental improvements in both merchandise and customer services, i.e. operational repositioning - they are constantly seeking to improve the attributes of their customer offer. EPOS has improved both the timeliness and the quality of information and market research now underpins both operational and strategic repositioning.

The stores have pursued a range of interrelated growth strategies based on a blend of broad differentiation and focus. Up-grading premises, improving instore ambience, extending the range of services and merchandise, maintains their mature market appeal and increases the likelihood of successful market penetration. All stores have improved product delivery. Extended trading now keeps the stores open beyond normal business hours and Sunday opening caters for both the time budget shopper and the leisure shopper. Enhanced store cards and affinity cards build customer loyalty and provide information for direct marketing. The added enrichment of car parking facilities brings the stores 'nearer' to car driving consumers.

All stores have engaged in strategic repositioning. Extensive product development, mainly driven by partnership concessions, has been a central plank in reorienting the stores to appeal to a younger customer. Research findings suggest a definite link between 
brands offered and store image. ${ }^{52}$ In the past, department stores have had little appeal for the youth market and most of their offers have been targeted to the more mature market which is deemed to be attracted by store ambience and service. If the stores succeed in retaining the mature market through operational repositioning while simultaneously attracting the younger, fashion conscious consumer, then they will have the best of both worlds. It makes sense for the department stores to attempt to broaden their appeal to a younger market segment. Although the Irish market is ageing, it is doing so more slowly than other European countries, the 1996 Census shows a relatively young age profile for the population of Dublin city and county: 71 percent of the population is under 45, and 30 percent is between 25 and 45. If the department stores can tap into an earlier stage of the life-cycle of Dubliners and achieve a degree of loyalty from a younger age group, then they have a greater chance of retaining them into the grey market. A counter-argument might suggest that targeting the younger market puts them in direct competition with international chains and that too many stores will now be aiming at the same target.

Although department stores in the UK may be scaling down their concession offer and building an own-brand repertoire, this trend is not overly evident in the Irish market. Indeed, it seems that for some stores, concessions are playing an increasingly important role, e.g. in 1993, concession sales accounted for 14\% of Arnotts turnover, by January 1997 this had risen to $24 . \%{ }^{53}$ Concessions are obviously a two-edged sword - while they generate welcome revenue their use has several down-sides. It seems ironic that department stores in Dublin have facilitated a relatively risk free market entry for many multiples by encouraging them to test demand via in-store concessions. Despite the short-term benefits of this strategy, it could be argued that the department stores, by hosting concessionary fashions, may develop loyalty to particular brands, rather than to the store itself. ${ }^{54}$ The need to have a complete fashion offering has encouraged the stores to tolerate an overlap in branded concessions while the surge in available retail space has enabled well-established concessions to move into independent units, in competition with the department store, but sometimes retaining their base in-store.

While the search for new market segments is vigorous, the search for new territories is not. Although two of the stores have located single departments in suburban shopping centres, none has expressed an interest in pursuing territorial expansion via shopping centre developments.

Each store has pursued some form of related diversification, risk cushioned by partnership alliances, which enhances the customer offer, e.g. credit cards, bureaux de change, computer software, and electrical goods.

\section{Divergent Approaches}

While the department stores appear to have chosen a homogenous approach to productmarket related growth, key differences emerge in the methods used to grow the businesses. 
Both Arnotts and Clerys have concentrated on growth through internal development, but there the similarity ends. Through good times and bad, Arnotts has pursued a consistently pro-active, high-risk strategy of expansion and has invested substantial resources to achieve its vision to be 'The Department Store' - the ultimate one-stop-shop. As a public company, listed on the stock exchange, Arnotts strategy of investing for the future does not appear to be plagued by the 'short-termism' sometimes associated with management decisions driven by accountability to shareholders.

Clerys, in contrast, is like a giant just awakening from slumber; there has been a time-lag in its reaction to both economic and market forces. In line with the theory articulated previously, in the highly competitive environment which pertains in Dublin, this reactive, relatively minimalist, slow growth, low-risk investment strategy carries, paradoxically, a very high risk. The appointment of a new chief executive in 1992 acted as a catalyst for change and the company is now moving into a higher gear.

Brown Thomas has pursued a strategy of growth through acquisition, which is unusual for Irish retailers. Two years after its acquisition, Brown Thomas implemented a high-risk strategy of killing-off its flagship acquisition, re-branding the original Switzers store, and building a different business. Retaining the best of both businesses allowed Brown Thomas to capitalise on synergy. The company is now pursuing an aggressive strategy of market development as it refurbishes and rebadges its acquired department stores in Cork, Galway and Limerick. Its location in the majority of Republic of Ireland cities now qualifies it as a national retailer and it should reap some benefits from critical mass. Obviously, Brown Thomas is hoping to exploit the product and service differentiation advantages of its brand name, but while the name Brown Thomas is known nationally, Irish consumers can sometimes be parochial and the advantages it enjoys in Dublin may not transfer to other cities. Only time will tell.

In terms of quality and customer responsiveness, all stores must score well, although Clerys is handicapped by a slow start. The stores constantly focus on innovativeness which distinguishes them easily from many high street competitors; homogenous high streets should serve to highlight the attractions of the department stores. However, it is difficult for any one of them to carve out an innovation which could not be copied by the others, e.g. while Arnotts has plans for a discount department, Clerys could probably imitate this if it chose to do so. However, this particular approach might be alien to Brown Thomas image.

Pro-active, high risk strategies should attract strong returns, especially in a buoyant economy. The following figures taken from consolidated balance sheets (acknowledging the limitations of consolidated balance sheets) show each company's turnover, operating profit and return on sales \% for 1996 and 1997. These results are interesting particularly when considered in the context of Berry's contention that the level of retailing effectiveness required for survival continues to increase. 
Table 1 Return on Sales

\begin{tabular}{|l|l|l|c|l|l|c|}
\hline Company & & 1997 & & & 1996 & \\
\hline & $\begin{array}{l}\text { Turnover } \\
\text { (millions) }\end{array}$ & $\begin{array}{l}\text { Op.Profit } \\
\text { (millions) }\end{array}$ & $\begin{array}{l}\text { R.O.Sales } \\
\%\end{array}$ & $\begin{array}{l}\text { Turnover } \\
\text { (millions) }\end{array}$ & $\begin{array}{l}\text { Op.Profit } \\
\text { (millions) }\end{array}$ & $\begin{array}{l}\text { R.O.Sales } \\
\%\end{array}$ \\
\hline Arnotts & 68.992 & 6.790 & 9.8 & 66.630 & 5.543 & 8.3 \\
\hline Brown Thomas & 73.220 & 4.954 & 6.8 & 69.483 & 7.158 & 10.3 \\
\hline Clery's & 20.615 & .491 & 2.3 & 22.501 & .703 & 3.1 \\
\hline
\end{tabular}

Source: Company Annual Reports (1997)

In terms of efficiency, Arnotts shows the best results with a respectable $9.8 \%$ return on sales, an improvement of $1.5 \%$ on 1996 and a turnover increase of 3.5\%. Brown Thomas appears to be improving effectiveness, but slipping in efficiency as turnover increased by $5.3 \%$, but operating profits fell, and return on sales slipped by $3.5 \%$. Overall, Clerys results must be considered disappointing, turnover is down by $8.4 \%$, operating profit is down by $30.1 \%$, and return on sales is down by $0.8 \%$. Despite a booming economy, it would appear that Clerys strategies have yet to bear fruit.

\section{Conclusion}

It would be fair to say that Dublin's traditional department stores have closed the gap in areas where they were previously disadvantaged: extended trading hours and car parks brings them in line with similar offers from shopping centre developments, upgraded merchandise and services enhances their appeal. Although the routes and methods have differed, broadly speaking, the stores have chosen to arrive at the same destination in terms of customer focus; the end result is more companies jockeying for position around a particular market segment.

By confining their attention to city-centre retailing, two of Dublin's traditional department stores have put all their eggs in one basket; Brown Thomas has extended its reach through acquisition. They all have confidence that their strategies will succeed and ensure their survival into the second millennium. 


\section{References}

${ }^{1}$ Euromonitor, (1997), 'Global Trends in Retailing'.

${ }^{2}$ Arnotts Annual Returns, June, 1997.

${ }^{3}$ See Anne Haverty, Elegant Times: A Dublin Story (Dublin: Sonas, 1995), Ronald Nesbitt, At Arnotts of Dublin: 1843-1993, (Dublin: A. and A. Farmar,1993) and Peter Costello and Tony Farmar,The Very Heart of the City: The Story of Denis Guiney \& Clerys, (Dublin: A. and A. Farmar,1992).

${ }^{4}$ Costello and Farmer,The Very Heart of the City.

${ }^{5}$ See Europe's Top City:Dublin, a report produced by the Dublin Chamber of Commerce to celebrate Dublin's award of 'Europe's Top City' (Dublin: Dyflin Ltd.,1997).

${ }^{6}$ Barry Berman and Joel R. Evans, Retail Management: a strategic approach, 7th ed. (New Jersey:Prentice Hall, 1998), p. 322.

${ }^{7}$ Con Power, 'City Centre Shoppers Vote With Their Feet', Business \& Finance, 1996

${ }^{8}$ Europe's Top City

${ }^{9}$ Ibid.

${ }^{10}$ Tony Parker; 'Feel good factors,' Retail Week, 17 March, 1995.

${ }^{11}$ Europe's Top City

${ }^{12}$ T.J. Baker, David Duffy and Fergal Shortall, 'Quarterly Economic Commentary', The Economic and Social Research Institute (Dublin: Argus Press, April, 1998).

${ }^{13}$ Central Bank End of Year Review, 1997, pp 97-98.

${ }^{14}$ Europe's Top City

${ }^{15}$ Central Bank Review, p.97.

${ }^{16}$ Baker, Duffy and Shortall

${ }^{17}$ Europe's Top City.

${ }^{18}$ Ita O'Kelly-Browne, 'Chainstore Massacre', Irish Independent, 22 August, 1996.

${ }^{19}$ Con Power, 'The changing face of the modern shopping centre', Irish Independent, 4 March, 1998.

${ }^{20}$ Gunne Estate Agents, Annual Review 1996.

${ }^{21}$ Gerry Johnson and Kevan Scholes, Exploring Corporate Strategy, 4th ed., (Prentice Hall Europe,1997) p.137.

${ }^{22}$ Charles W.L. Hill and Gareth R. Jones, Strategic Management: an Integrated Approach, (Boston: Houghton Mifflin Co., 1998), p. 113.

${ }^{23}$ H. Ansoff, Corporate Strategy, (Penguin, 1988); Michael Porter, Competitive Advantage,(Free Press, 1985).

${ }^{24}$ David Walters, Retailing Management: Analysis, Planning and Control, (Basingstoke: The MACMILLAN Press, 1994), p. 272

${ }^{25}$ M.S Moyer, 'Market Planning in Retailing; making the basics work', paper presented to the Marketing Education Group, Cranfield, July,1983.

${ }^{26}$ Colin Gilligan \& Clive Sutton 'Strategic Planning in Grocery and DIY Retailing', Business Strategy in Retailing, ed. G. Johnson, (Chicester: John Wiley \& Sons, 1987), p.177.

${ }^{27}$ Glenn A. Omura, 'Developing Retailing Strategy' in International Journal of Retailing, Vol:1 No:3 1986, p.17.

${ }^{28}$ Melody Lanette Adkins LeHew, 'US Mall Marketing Managers' Market Awareness: A Strategic Imperative?', paper presented at 9th International Conference on Research in the Distributive Trades, Belgium, July 1997.

${ }^{29}$ Gary J. Davies and Janice M. Brooks, Positioning Strategy in Retailing, (London: Paul Chapman,1989), p.42.

${ }^{30}$ Shiv Sahai Mathur, 'How firm compete: a new classification of generic strategies' in Journal of General Management, Vol.14, No.1 Autumn 1988, p.32.

${ }^{31}$ Ibid., p. 52.

${ }^{32}$ Hill and Jones, p.222.

${ }^{33}$ Edmund O'Callaghan \& Mary Wilcox 'Dublin as an International Location: Perceptions and Experience', paper presented at the EIRASS 5th Recent Advances in Retailing \& Services Science Conference, Arizona, July, 1997.

${ }^{34}$ L. L. Berry, 'Stores with a future', Retailing Issues Letter, 7 (2) March, 1995. p. 1-4. 


\footnotetext{
${ }^{35}$ Several authors, to a lesser or greater extent, bemoan the failure of department stores to stay abreast of industry changes, see Avijit Ghosh, Retail Management, 2d ed. (Orlando:The Dryden Press,1994), p.333; J. Willans, 'Department Stores: An Enduring Retail Format', Journal of Fashion Marketing and Management, Vol.1, no. 2 (1996) p.146; R.A. Raunch, 'Retailing's dinosaurs: department stores and supermarkets', Business Horizons (USA), September/October, 1991 pp.21-25; Retail Insights, 'The Future for Department Store Retailing', Spring, 1996.

${ }^{36}$ Davies and Brooks, p.43.

${ }^{37}$ Gerry Johnson, 'Strategies and Strategic Positioning in Retailing' in Business Strategy in Retailing, ed. G. Johnson, (Chicester: John Wiley \& Sons, 1987), pp. 83-84

${ }^{38}$ Walters, p.13.

${ }^{39}$ Verdict (1987), Verdict on Retail Market Segmentation, Verdict Research, London.

${ }^{40}$ Johnson and Scholes, p.262

${ }^{41}$ Richard Ford, 'Some Perspectives on Retailing in the 1990s', International Journal of Retail \& Distribution Management, Vol. 19 no. 5, (1991), p.20.

${ }^{42}$ Johnson \& Scholes, p. 262.

${ }^{43}$ John McGee, 'Retailer Strategies in the UK', Business Strategy and Retailing, ed. G.Johnson.

${ }^{44}$ Retail Insights, Spring 1996.

${ }^{45}$ Davies and Brooks. p. 48.

${ }^{46}$ Johnson \& Scholes, p. 255

${ }^{47}$, Keith Bradley and Simon Taylor, Business Performance in the Retail Sector, (Oxford: Clarendon Press, 1992), p. 22.

${ }^{48}$ Ibid., p. 31.

49 'British shoppers are getting better service but there are still serious problems in some sectors',

International Journal of Retail and Distribution Management, i-xii p.v (centre section) Volume 23, Number 5, 1995.

${ }^{50}$ David J. Rachman, Swee L. Chia, 'International Strategy of U.S. Retailers and the Role of Market Research', The Changing Retail Scene:Opportunities, Threats and Innovation,ESOMAR Seminar on Retailing Research, Madrid, 5-7 November, 1997; Lynda Chong,'Department stores in troubled waters: a Singapore encounter', International Journal of Retail \& Distribution Management, Vol. 24, no.1,1996, pp. 34-39; 'Department Store Dilemma', Retail Week, 7 October, 1994; Retail Insights.

${ }^{51}$ Anne Haverty, Elegant Times. p.109.

${ }^{52}$ Jacon Jacoby and David Mazursky, "Linking Brand Name and Retailer Images: Do the Potential Risks Outweight the Potential Benefits?" Journal of Retailing 60 (Summer 1984), pp. 105-122

${ }^{53}$ Extracted from Arnotts Annual Report, 1997.

${ }^{54}$ Retail Insights, Spring 1996
} 